\title{
Contributions towards a Knowledge of the Anatomy of the Genus Selaginella, Spr.
}

\author{
BY
}

\author{
R. J. HARVEY GIBSON, M.A., F.L.S., \\ Professor of Botany in University College, Liverpool.
}

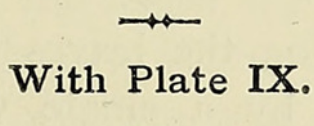

PART III. THE LEAF.

\begin{abstract}
AONGST the older monographs, the first important A contribution to our knowledge of the anatomy of the leaf of Selaginella occurs in Hofmeister's treatise on the Structure and Development of the Higher Cryptogams ${ }^{1}$. Dealing more especially with the species $S$. denticulata, S. Galeottei, and S. Martensii, he first of all gives an account of the mode of development of the leaf, describing it as arising as a horizontal ridge of cells, embracing about one quarter of the circumference of the stem, and first appearing about eight or ten cells behind the apical cell. The cells forming the ridge undergo division in such a manner as to give origin to a plate two cell-layers in thickness, the central cells of the ridge dividing more actively than those nearer the edge. On either side of the middle line the cells undergo

1 Vergleichende Untersuchungen der höheren Kryptogamen. Leipzig, I85 I.
\end{abstract}

[Annals of Botany, Vol. XI. No. XLI. March, 1897.] 


\section{I24 Gibson.-Contributions towards a Knowledge of}

divisions parallel with the surface, forming a central core, which afterwards becomes the vascular bundle. At the same time the apex of the young leaf becomes elongated, and the cell-walls in this region become thickened. Division and growth now progress rapidly at the leaf-base, the cells of the lower surface being more active in this respect than those of the upper side. Hofmeister then describes the further modifications in the course of transition to the adult form, attention being drawn to the formation of marginal papillae and hairs, and the development of rows of warts on the cells near the margin of the leaf. He further points out that the median cells of the leaf are arranged so as to form a network with conspicuous intercellular spaces, whilst at the margins the mesophyll is wanting, and the upper and under epidermal layers are in contact.

Russow ${ }^{1}$, in describing the leaves in the genus, speaks of the leaf as traversed by a single vascular bundle, which terminates before the apex of the leaf is reached. The xylem consists of spiral and reticulate elements, and is surrounded by a scanty phloem. No endodermis is developed. The ground-tissue, he states, consists of spongy mesophyll, well developed in the more robust species, but only surrounding the vascular bundles in those with more delicate leaves. Russow draws special attention to the epidermis of the leaf, and shows that it varies considerably both in the form and in the nature of the cells of which it is composed. In some species (e. g. S. Kraussiana and S. Galeottei) the upper and under epidermal layers are alike, and he suggests that probably the leaves of all species belonging to the section 'Articulatae' have this structure. Of Spring's section 'Articulatae' (which is not synonymous with that of Baker) I have examined only one other species in addition to those mentioned by Russow, viz. S. sulcata, and in that species the upper epidermis is quite similar to the lower. In other cases, Russow continues, the cells of the ligular face are shorter

1 Vergleichende Untersuchungen über Leitbündel-Kryptogamen. Mém. Acad. Imp. St. Pétersb., I 872 . 
than those of the aligular face, as in S. Lyallii, S. cuspidata, and pilifera. In the majority of the species the epidermis of the ligular face consists of polygonal cells almost or quite isodiametric, and appearing conical in transverse sections of the leaf, whilst the epidermis of the aligular face consists of elongated cells rounded or quadrate in section. Russow further points out that with regard to the smaller (dorsal) leaves, the cells of the ligular face correspond to those of the aligular face of the larger (ventral) leaves, and those of the aligular face of the smaller leaves to the cells of the ligular face of the larger leaves. The elongated epidermal cells contain several small chloroplastids, the conical cells generally two, or occasionally three, chromatophores only. In some species (e. g. S. Kraussiana) a layer of conical cells occurs beneath the epidermis of the ligular surface of the larger leaves and of the aligular surface of the smaller leaves, whilst in S. Lyallii this rudimentary palisade-layer becomes well marked. Stomata are described as occurring only on the aligular face, but exceptionally in $S$. pubescens ( $=S$. Braunii, Bak.) stomata occur on both surfaces of the smaller leaves ${ }^{1}$. Of the species mentioned by Russow as having stomata on the aligular surface only, I have examined all, and have been somewhat surprised to find that no less than three of them, viz. $S$. Kraussiana, S.cuspidata, and S.pilifera, had stomata on both sides of both dorsal and ventral leaves. Lastly, Russow calls attention to the peculiar cells of the epidermis of the ligular face of the larger and the aligular face of the smaller leaves (Doppelkegeln) in S. uncinata, and to the development of sclerotic fibres at the margins and on the surface of certain species, e. g. S. Martensii and S. stenophylla.

Treub ${ }^{2}$ has studied the mode of development of the leaf in S. Martensii. His results agree in the main with those of

1 'Bei $S$. pubescens finden sich auf beiden Flächen der kleinen Blätter Stomata; bei allen übrigen untersuchten Arten war nur die Epidermis der Aligularfläche, sowohl bei grossen als kleinen Blättern, mit Spaltöffnungen versehen.' Russow, l. c., p. I 38 .

${ }^{2}$ Les Organes de la Végétation du Selaginella Martensii, Spr. Leide, 1877. 


\section{I26 Gibson.-Contributions towards a Knowledge of}

Hofmeister. I do not purpose in the present paper to enter into the question of the development of the leaf, reserving that point for discussion in connexion with the structure of the stem-apex on which I am at present engaged.

In a brief note read before the British Association in 1887 , $\mathrm{McNab}^{1}$ points out that in S. densa, Hort., S. Poulteri, Hort., and S. Kraussiana, A.Br., a triple row of stomata is developed along each margin, one row above, one below, and one actually on the margin itself. All three species want the sclerotic marginal cells so commonly found in that situation.

Haberlandt's important paper on the chloroplastids ${ }^{2}$ may next be noted. In this treatise he gives a very full account of the structure and development of the chlorophyll-bodies. In the present contribution I have omitted any discussion of these, simply because I have nothing of any importance to add to Haberlandt's account.

I may next refer to Dangeard's account of the structure of the leaf ${ }^{3}$. He distinguishes two distinct types of leafstructure: $(\alpha)$ where the upper and lower epidermal layers are similar, and (b) where they are dissimilar. Under the first type two sub-sections are constituted: (I) leaves in which the mesophyll is homogeneous, e. g. S. spinosa, \&c. ; and (2) leaves in which the mesophyll is heterogeneous, e. g. S. Kraussiana, \&c. The leaves in the former sub-section have an epidermis composed of elongated (in the long axis of the leaf) rectangular cells, while the mesophyll consists of long, branched, narrow cells with numerous intercellular spaces ; in the latter section the mesophyll is subdivided into two distinct layers, an upper palisade-layer composed of conical cells perpendicular to the epidermis, and a lower spongy layer. The type of leaf with dissimilar epidermal layers Dangeard further describes as having homogeneous reticulate mesophyll throughout.

1 On the Stomata and Ligules of Selaginella. Brit. Assoc. Reports, 1887.

2 Die Chlorophyllkörper der Selaginellen : Flora, I888.

3 Essai sur l'Anatomie des Cryptogames vasculaires: Le Botaniste, I889, p. 247 . 
The stomata he describes as distributed, as a rule, over the midrib on the aligular face of the leaf, more rarely over the entire aligular surface. In the Rosulatae group (e. g. S. convoluta, S. cuspidata, \&c.) stomata, according to Dangeard, occur on both sides of the leaf. He also draws attention to the sclerotic cells of the epidermis of several species, and to the uni- (or more rarely pluri-) cellular hairs which occur along the margins of some leaves. Dangeard finally describes the vein as composed of a small cluster of protoxylem-elements only surrounded by phloem, adding "le faisceau de cette nervure ne possède jamais de métaxylème comme celui de la tige.' On this point he is at variance with Russow, who speaks of the xylem as being composed of 'Schrauben- und Netzzellen.' In S. sulcata Dangeard describes the phloem as limited to the under surface of the bundle, and points out the occurrence of bast-fibres (fibres libériennes) in the phloem of S. stenophylla. He again differs from Russow in asserting the presence of an endodermis, though 'certainement mal différencié.' Wojinowić ${ }^{1}$, in his thesis on Selaginella lepidophylla, gives an exhaustive account of the structure of the leaf, calling attention especially to the presence of stomata on both sides of the ventral leaf, and to their absence from the aligular face of the dorsal leaf. He says, speaking of the latter, "Die Epidermis dieser Seite (der organischen unteren, vom Stengel abgewendeten Seite) führt keine Spaltöffnungen,' and again, 'In der Epidermis der organischen Oberseite (d. h. der dem Stengel anliegenden) finden sich Spaltöffnungen.' In this statement he is supported by Erikson (l.c.), who says, in discussing the dorsal leaf, 'Epidermis på den undre (uppåtvända) ytan består af långsträckta celler med tunna, nästan rake mellanvägger och saknar klyföppningar. På den öfre (inåtvända) sidan finnas ytterst talrika klyföppningar, hvilka äro strödda öfver hela ytan.' I have examined a very large number of specimens from the Botanic Gardens of Kew, Strassburg, Glasgow, \&c., and in all cases I found that the

1 Beiträge zur Morphologie, Anatomie und Biologie der S. lepidophylla, Spr. Breslau, I 890. 


\section{28 Gibson.-Contributions towards a Knowledge of}

dorsal leaves, as in the case of the ventral leaves, bear stomata on both sides.

Erikson's monograph ${ }^{1}$ deals in considerable detail with the leaf-structure in the Lycopodiaceae. The author has examined thirty species of Selaginella, apparently chiefly from herbarium material; of these I have examined twenty. His work, to a large extent, covers the same ground as my own; still, as I have had opportunities of studying thirty-two species which Erikson has not had access to, and as I am able to supplement to some extent many of his observations, and to add several points which he has not touched, I may venture to consider his memoir as not rendering the publication of the present paper altogether unnecessary. Into the details of his work I need not at present go, but merely give, for convenience of comparison, his scheme of classification of the species according to their leaf-structure. Erikson distinguishes three types of leaf: the first division includes such as have leaves with the upper epidermal cells conical and with, at the same time, a homogeneous spongy mesophyll, e.g. S. Martensii, \&c.; the second group includes those which have leaves provided with a distinct palisade-layer, some of these, like $S$. Kraussiana, with upper and under epidermal layers similar, others, like $S$. Wildenowii, with upper epidermis different from the under. The third group have leaves without palisade-layers, again subdivided into those with a similar epidermis above and below, e.g. S. spinosa, and those with epidermis above and below dissimilar, e.g. S. serpens. In comparing Erikson's scheme with that of Dangeard, it will be seen that the former takes the presence or absence of a palisade-layer as the basis of primary division, and subdivides the groups according to whether the epidermis of the upper side is like that of the lower side or unlike; whilst Dangeard selects the character of the epidermis as his primary basis of classification, and subdivides according to the nature of the mesophyll. It seems to me quite immaterial which plan is

1 Bidrag till Kännedomen om Lycopodinebladens Anatomi: Arbet f. Lunds Bot. Instit., I 892 . 
adopted, although Dangeard's method is perhaps the simpler of the two. It has the further advantage of being based on a somewhat more constant character, although neither the nature of the epidermis nor the composition of the mesophyll, singly, seems to me to afford a perfectly satisfactory basis. In the order of description of the species I have therefore combined these two characters. The great majority of the species which I have examined (thirty-two out of fifty-three) have the epidermal layers different in character, and show in section a reticulate mesophyll without any very definite palisadelayer. Three additional species with very delicate leaves have practically no mesophyll, but possess the epidermal characters of the same nature as those of the majority. The remaining species have the upper and under epidermis practically alike; some, however, of these have, and others have not, a distinct palisade-layer. I have examined several hundred leaves, and find scarcely one of the characters I have mentioned at all constant. Even on the same epidermal surface, one finds elongated cells in one part and quite short polygonal cells in another. Again with regard to the mesophyll, many species show a quite distinct tendency to form a palisade-layer (though not a compact one) where, on the whole, one would consider the mesophyll to consist of reticulate parenchyma only. As for the stomata, these are most variable in their distribution, being situated sometimes on the ligular, sometimes on the aligular, and sometimes on both surfaces; sometimes over the midrib only, sometimes on the wings, sometimes generally all over the surface.

In the arrangement of the present paper I purpose first to give a brief account of the peculiarities of the leaves of each species, and thereafter to add one or two notes on special points, such as the structure and development of the stomata and the histology of the vascular bundle. I had occasion in a recent paper ${ }^{1}$ to draw attention to the necessity of considering the internal anatomy in the classification of the very

1 On the diagnostic characters of the subgenera and species of Selaginella, Spr. : Trans. Biol. Soc. Liverpool, 1895 . 


\section{30 Gibson. Contributions towards a Knowledge of}

numerous species. I was led from a study of the stemstructure to arrange the species somewhat differently from the scheme adopted by systematists. It will be interesting finally to see in how far the anatomy of the leaf supports or refutes the views expressed in that paper.

\section{Section I. Anatomy of Species.}

\section{A. Martensii-Tуре.}

All the species coming under this heading have the epidermis on the ligular and aligular surfaces of the leaves dissimilar, and a mesophyll consisting of reticulate parenchyma. (It will be understood that, to save repetition, the chief differences in histology will alone be pointed out. Unless otherwise stated, the characters in the various species are those described in the type-species.)

1. S. Martensii, Spr. Pl. ix, Fig. 3.

Ventral leaf. The leaves are lanceolate, somewhat elongated, and unequal-sided with narrow, bluntly pointed apices. The margin consists of elongated sclerotic fibres, from which numerous unicellular trichomata arise. The cells of the ligular epidermis are polygonal, wavy on surface view, conical in section. No stomata occur on this face. The aligular face consists chiefly of elongated plate-like cells with sinuous margins, amongst which occur scattered sclerotic fibres. The stomata are in several rows over the midrib, and the epidermal cells are often sclerotic in the neighbourhood. Occasionally stomata occur on the lamina, near the margin of the leaf. Near the stomata the epidermal cells are considerably shorter. Cuticular warts occur on the surface of the marginal cells.

Dorsal leaf. The leaves are ovoid oblique with well-marked apices, and the margins bear numerous unicellular trichomata. The ligular epidermis consists of elongated, wavy-bordered cells without stomata. The aligular surface consists of polygonal sinuous cells, peg-shaped in section, with numerous stomata. Very many of these stomata have their guard-cells surrounded by strongly thickened epidermal cells, especially on the walls touching the guard-cells (Fig. 3). 
the Anatomy of the Genus Selaginella, Spr. I 3 I

Section. (Unless otherwise stated, the section described is that of the ventral leaf.) On the ligular face the cells are cuticularized and obconic, and rest on the lower or aligular epidermis at the margins, but are separated from it in the thicker regions of the leaf by reticulate mesophyll.

\section{S. grandis, Moore.}

Ventral leaf. The leaves are long, rhomboidal, and sharply acuminate, on the whole equal-sided, and bear shorter or longer spines on the base only. The ligular epidermis consists of polygonal cells, becoming more elongated and wavy towards the margins. A few stomata occur on this face. The aligular epidermis consists of elongated sinuous cells, becoming shorter over the midrib and having scattered sclerotic warty fibres. The stomata are in several rows over the midrib.

Dorsal leaf. The leaves are ovoid pointed oblique with long: spiny apices. The ligular face bears no stomata, though these are numerous on the aligular surface. Epidermis as in the type.

Section. As in S. Martensii.

\section{S. Vogelii, Spr.}

Ventral leaf. Leaves triangular ovoid, with blunt apices and without marginal spines. Stomata occur on both ligular and aligular surfaces, though more numerous on the latter.

Dorsal leaf. Leaves oblique ovoid, small, with long apices and without marginal spines. Stomata occur on the aligular surface only.

Section. As in the type.

4. S. haematodes, Spr.

Ventral leaf. Leaves oblique, ovoid, acute, faintly spiny on the outside margin. The polygonal cells of the ligular face become long and wavy bordered nearer the margins; no stomata. The walls of the aligular epidermal cells have irregular thickenings similar to those figured as occurring in $S$. producta (Fig. 6). The stomata are surrounded by similar cells, and warty sclerotic fibres occur among the epidermal cells.

Dorsal leaf. Leaves ovoid, oblique with a long cusp; margin faintly spiny. The ligular epidermis has no stomata, but has the same irregular thickenings that occur in the cells of the aligular epidermis of the ventral leaf. The aligular epidermal cells are

$$
\text { K } 2
$$




\section{I32 Gibson.-Contributions towards a Knowledge of}

polygonal, becoming longer towards the margins. The stomata are surrounded by irregularly thickened cells.

Section. As in the type.

5. S. erythropus, Spr.

Ventral leaf. Ovate, oblique, curved, with numerous marginal trichomata with red contents. Stomata occur near the base on the outer region of the ligular epidermis. The elongated cells of the aligular face are not wavy, the cells near the, stomata becoming polygonal.

Dorsal leaf. Similar in form to the ventral leaf, but with a long cusp. The ligular face bears numerous stomata distributed over the outside half of the leaf. The marginal cells are sclerotic and warty. The cells of the aligular face are long at the margins, shorter near the midrib where the stomata occur.

Section. The cells composing the reticulum are shorter and more rounded than in the four preceding species.

6. S. caulescens, Spr.

Ventral leaf. Ovate, curved, pointed, with marginal unicellular spines. Stomata occur near the base of the ligular face of the leaf. The cells of the aligular surface are elongated, but not wavy, though warty. The aligular face bears numerous stomata.

Dorsal leaf. Similar in form to the ventral leaf, but with a longer cusp. Stomata occur on the aligular face only.

Section. As in the type.

In var. argentea there are no stomata on the ligular surface of the ventral leaf. In var. japonica and var. minor the ligular surface of the ventral leaf has stomata near the base, and the epidermal cells are elongated on one side of the midrib and polygonal on the other. On the aligular face of the dorsal leaf in these varieties a few sclerotic cells occur on either side of the midrib. I draw attention to these small histological differences by way of emphasizing the great variation that occurs in the leaf-characters.

7. S. Griffithii, Spr.

Ventral leaf. Unequal-sided, awl-shaped, pointed, spiny. Marginal sclerotic warty cells on the gibbous side. A few stomata occur on the ligular face near the margin of the leaf. Numerous stomata and sclerotic fibres on the aligular surface. 
Dorsal leaf. Ovate, with long cusp; margins warty and spiny. Sclerotic fibres occur among the ligular epidermal cells, though no stomata are present on this face. These are, however, numerous on the aligular face.

Section. As in the type.

8. S. Karsteniana, A. Br.

Ventral leaf. Leaves large, very oblique ovoid, blunt apically and with basal wings, very faintly spiny. The polygonal cells of the ligular surface are more elongated and wavy towards the margins; stomata are absent. Sclerotic warty fibres occur on the aligular surface. The stomata are very peculiar. Frequently the walls of the guard-cells are so much thickened as to almost or quite obliterate the lumina, as I have figured in S. concinna (Fig. 7). The surrounding epidermal cells are also greatly thickened. It is difficult to see how these stomata can serve any physiological purpose, at least in the mature leaf. I may say in this connexion that I invariably examined leaves taken from several parts of the plants studied, avoiding the very young leaves near the apex, and the old leaves on the basal regions of the stem.

Dorsal leaf. Leaves ovate pointed and faintly spiny. Stomata occur both on and near the margins. The stomata on the aligular face were in many cases sclerotic, as in the case of the ventral leaf,

Section. As in the type.

\section{S. suberosa, Spr. (Fïg. I 9.)}

Ventral leaf. Ovate-lanceolate, bluntly pointed with spiny margins. The margins have warty sclerotic cells every here and there, except where marginal stomata occur. Warty sclerotic fibres also occur among the aligular epidermal cells, the stomata being confined to the region over the midrib.

Dorsal leaf. Ovate with backwardly directed wings, spiny sclerotic margin, and a long cusp. No stomata occur on the ligular face. The sclerotic fibres on the aligular face are very long, thick-walled, highly refractive, and warty. Stomata occur over the midrib, and a very few at the margins of the basal lobes.

Section. As in the type.

Fig. I 9 shows a section of the ventral leaf. The ligular epidermis consists of peg-shaped cells with every here and there sclerotic fibres. 


\section{I34 Gibson.-Contributions towards a Knowledge of}

One of these is shown in section. The reticulate mesophyll is of the usual nature common to species belonging to this type. Two warty sclerotic fibres cut across are shown in the aligular epidermis.

10. S. stenophylla, A. Br.

Ventral leaf. Oblong-ovoid, bluntly pointed, and slightly spiny. Sclerotic warty fibres occur on the ligular face; warty sclerotic marginal cells alternate with marginal stomata. Similar sclerotic fibres occur on the aligular face, where there are numerous stomata.

Dorsal leaf. The leaf is ovate with a long cusp and spiny margin. The marginal cells are sclerotic, and the leaf has backwardly directed lobes as in S. Karsteniana. No stomata occur on the ligular face, though there are numerous sclerotic warty fibres. These also occur on the aligular face. The stomata occur not only over the midrib, but at the margins as well.

Section. As in the type.

The vascular bundle of the leaf of this species will be referred to later.

11. S. viticulosa, Klotz. (Figs. 2, 9, I0, I6, 22.)

Ventral leaf. Ovate, oblique, bluntly pointed, with short basal lobes. The margin is formed of elongated pitted cells, from almost every one of which unicellular spines arise. The spines are much shorter near the apex. Stomata occur on the aligular face only, in 4-5 rows over the midrib. Many of these have sclerotic walls (Figs. 9, I0), and not infrequently one meets with abnormal stomata with three guardcells (Fig. IO); whilst on some leaves I have found the stomata grouped in twos and threes (Fig. 2). All the cells of the aligular surface are elongated and sinuous, and provided with two rows of cuticular warts (Fig. I6). The cells near the midrib are shorter and have less sinuous walls. The cells of the ligular face are wavy and polygonal, but become more elongated towards the margin of the leaf; there are no stomata on this face.

Dorsal leaf. Ovate pointed, oblique, with long cusp. The margin is spiny, and the trichomes are especially long on the basal lobes. Several of the epidermal cells of the aligular surface of the basal lobes bear trichomata. Stomata occur in four or more rows over the midrib on the aligular face; a few also occur on the inside lobe. The stomata are often sclerotic and abnormal, as in the case of the ventral leaf. No stomata occur on the ligular face.

Section. As in the type. 


\section{the Anatomy of the Genus Selaginella, Spr. 135}

12. S. serpens, Spr. (Figs. 4, I 4, 29.)

Ventral leaf. Ovoid, blunt, with sclerotic spiny margins (Figs. 4, I 4). The cells of the ligular epidermis are polygonal or rounded, becoming elongated with sinuous lateral walls on the basal lobes. The elongated cells of the aligular surface are provided with one row of warts; the cells become shorter near and over the midrib. Stomata occur on this side only.

Dorsal leaf. The leaves are ovoid, cuspidate, very oblique, and the margin is more sclerotic than in the ventral leaf. Stomata occur on both sides-on the aligular side, where they are frequently sclerotic, over the midrib; and on the ligular side on the outside lobe. The elongated cells of the ligular epidermis have $3-4$ rows of warts.

Section. As in the type, but the mesophyll-cells are short and closely packed (Fig. 29).

13. S. cuspidata, Lk.

Ventral leaf. The leaves are broadly ovate, and cuspidate with a broad marginal band of sclerotic fibres, trichomatous especially towards the base. These marginal cells have no chloroplastids. Stomata occur on the ligular face occasionally, especially on the margins of the basal lobes. The aligular epidermal cells are elongated but not wavy; there are numerous stomata.

Dorsal leaf. The leaves are almost as large as those of the ventral side, and similar in form and margin. Stomata occur on the lamina, but not over the midrib, of the ligular face. Numerous stomata occur on the aligular face.

Section. As in the type.

14. S. helvetica, Lk, (Fig. 23.)

Ventral leaf. Leaves awl-shaped, bluntly pointed, unequal-sided, and faintly spiny. The epidermis of the ligular face, which bears no stomata, consists of polygonal cells over most of the surface, but of elongated cells over the basal and apical regions.

Dorsal leaf. The dorsal leaves are nearly as large as the ventral, and of similar shape and histological characters. Stomata occur near and over the midrib on the aligular face, and sparingly also at the edge near the base. On the ligular face stomata also occur over the middle and edge. Their walls are often sclerotic.

Section. The mesophyll consist of rows of elongated cells, which curve upwards from the ventral to the dorsal surface (Fig. 23). 


\section{I36 Gibson.-Contributions towards a Knowledge of}

\section{S. denticulata, Lk.}

Ventral leaf. Ovate, somewhat cordate, faintly spiny. Stomata occur on the aligular surface only, over the midrib and wings; a few occur near the margins.

Dorsal leaf. Similar in shape to the ventral, but smaller; faintly spiny. Stomata occur on both sides.

Section. As in the type.

\section{S. patula, Spr. (Fig. I I.)}

Ventral leaf. Lanceolate, oblique, abruptly pointed, with marginal trichomata at the base, spiny at the apex. Stomata occur along the edge of the ligular surface where the ordinary polygonal cells of this surface become longer. The aligular cells (Fig. I I) are partly sclerotic, and each bears one or two rows of cuticularized warts. The cells are shorter over the midrib where the stomata occur.

Dorsal leaf. Leaves ovate, cuspidate with marginal trichomata. Stomata occur on the ligular face near the base. The aligular epidermal cells are warty.

Section. As in the type.

\section{S. convoluta, Spr.}

Ventral leaf. Oblique sickle-shaped, acute, with spiny margins; the lamina near the margins one cell thick. The aligular surface only bears stomata.

Dorsal leaf. Ovate, oblique, acute, with spiny margin. Both ligular and aligular surfaces bear stomata. The cells of the aligular face are, in most parts of the leaf, nearly as long as those of the ligular surface.

Section. Reticulate mesophyll between the two epidermal surfaces, but the upper cells (ligular) are closely packed and form a pseudopalisade-layer. Dangeard speaks of stomata on the ligular as well as on the aligular face of the ventral leaf. As I have above stated, this is true of the dorsal leaf (which Dangeard does not refer to in this relation), but I have been quite unable to find stomata on the ligular face of the ventral leaf.

18. S. flabellata, Spr.

Ventral leaf. Oblique ovate, bluntly pointed, faintly spiny along one side. On both ligular and aligular surfaces the epidermal cells vary in length. 
Dorsal leaf. Similar in shape to, but one-third the size of, the ventral leaves. The stomata which occur only on the aligular face are frequently sclerotic.

Section. As in the type. Dangeard's figure of the transverse section of the leaf (l.c., Plate XI, Fig. 2o) shows no intercellular spaces. This is quite incorrect.

\section{S. producta, Bak. (Figs. 5, 6.)}

Ventral leaf. Cordate, oblong-lanceolate, unequal-sided, with sclerotic margins, faintly spiny at and near the base. The aligular epidermis consists of the usual elongated wavy-bordered cells, with many sclerotic fibres interspersed. The stomata are almost all sclerotic (Fig. 5), the lumina of the surrounding epidermal cells being sometimes almost occluded. The epidermal cells also have numerous irregular thickenings on the lateral and end walls (Fig. 6).

Dorsal leaf. Similar to those of the ventral side, but cuspidate. The aligular and ligular epidermal surfaces are similar to those of the ligular and aligular surfaces of the ventral leaf respectively. The stomata, which occur on the aligular face only, are sclerotic. long.

Section. As in the type, save that the mesophyll-cells are very

20. S. bisulcata, Spr.

Ventral leaf. Oblique, ovate, bluntly pointed with spiny margin. The ligular epidermis bears numerous marginal stomata from base to apex. The margin has a warty sclerotic border. Stomata occur over the entire aligular surface.

Dorsal leaf. Oblique, ovoid, cuspidate with spiny sclerotic margins. Stomata occur only on the aligular surface.

Section. As in the type.

\section{S. uncinata, Spr. (Figs. I 2, I3.)}

Ventral leaf. Leaves oblique, oblong, subsessile, with quite smooth (non-hairy) but sclerotic margins. Stomata occur on the aligular face only, the guard-cells having two large chloroplastids in each.

Dorsal leaf. Ovate, with smooth sclerotic margin. Stomata on the aligular face only.

Section. As in the type.

The development of the stomata is discussed in Sect. II. 


\section{38 Gibson.-Contributions towards a Knowledge of}

22. S. plumosa, Bak. (Fig. 2 r.)

Ventral leaf. Oblong pointed, spiny but non-sclerotic margins. Several stomata occur on the outside marginal region of the ligular face as well as over the midrib on the aligular face.

Dorsal leaf. Broadly ovate and suddenly acuminate with spiny margins. No stomata occur on the ligular face.

In section the leaf of the species approaches that of $S$. Wildenowii, the peg-shaped ligular epidermal cells being followed by a layer of small cells with large chloroplastids - a pseudo-palisade-layer-followed in turn by a reticulum of larger rounded cells, abutting on the aligular epidermis (Fig. $2 \mathrm{I}$ ).

\section{S. Douglasii, Spr. (Fig. I.)}

Ventral leaf. Ovate, oblique, bluntly pointed, with a few hairs on the basal lobes. The spines are commonly sheathed at the base by marginal leaf-cells. The margin is not sclerotic, but the cells are warty. Stomata occur on both faces, over the outside of the basal lobe on the ligular face, and over the midrib on the aligular face.

The dorsal leaf is similar in shape with a cusp provided with hooked spines. The margin is similar to that of the ventral leaf. Stomata occur on both surfaces.

In section the leaf shows a reticulate mesophyll only-there are no palisade-cells.

Both of these species (22 and 23) show a tendency to have the ligular and aligular epidermis composed of somewhat similar cells, and thus form a transition to types $\mathrm{B}$ and $\mathrm{C}$.

The succeeding ten species conform in the structure of their leaves to the Martensii-type, although their stem-anatomy shows a distinct advance, having three or more steles instead of one.

24. S. inaequalifolia, Spr.

Ventral leaf. Oblique awl-shaped, bluntly pointed, with sclerotic faintly spiny margins. The axillary leaf resembles the ventral, save that the lamina is equalized. Stomata occur on the aligular face plentifully, and a few also occur near the margin on the ligular face.

Dorsal leaf. Similar in shape to the ventral leaf, but narrower. Stomata occur on the aligular face only.

Section. Similar to that figured for S. Wildenowii (Figs. 30, 3 I). 


\section{the Anatomy of the Genus Selaginella, Spr.}

\section{S. Wallichii, Spr.}

Ventral leaf. Oblong oblique, bluntly pointed, without marginal spines. Stomata occur on the margin on the ligular face, as well as abundantly on the aligular surface.

Dorsal leaf. Similar in shape but cuspidate. Stomata occur on both ligular and aligular surfaces.

Section. As in S. Wildenowii.

26. S. Wildenowii, Bak. (Figs. 30, 31.)

Ventral leaf. Oblong, unequal-sided, with crenate non-spiny margins. Stomata occur on the aligular face only.

Dorsal leaf. Oblong, unequal-sided, cuspidate. Stomata distributed over the aligular face only.

Section. The ligular epidermis in section is composed of obconic cells with one or two large chloroplastids in each, having their truncated apices continuous with a reticulate mesophyll. The aligular epidermal cells are much deeper in the centre than where they touch each other. The walls of the guard-cells are frequently thickened.

27. S. canaliculata, Bak. (Fig. 20.)

Ventral leaf. Awl-shaped, or rhomboid with a sclerotic margin and a few spines near the apex. A few stomata occur near the margin of the ligular surface, as well as abundantly on the aligular face.

Dorsal leaf. Similar in shape but cuspidate. Stomata occur on the aligular face only.

Section. As in $S$. Wildenoreriz, save that in most of the lamina the reticulate mesophyll is wanting, and the ligular peg-shaped cells rest directly on the aligular epidermis (Fig. 20).

28. S. Mettenii, A. Br.

Ventral leaf. Oblong, obtuse, pointed, with sclerotic faintly spiny margins. A very few stomata occur along the margin of the ligular face. Stomata are generally distributed over the aligular surface.

Dorsal leaf. Ovate, oblique, with sclerotic non-spiny margins. The stomata occur on the aligular face only.

Section. The vascular bundle runs the whole length of the leaf. The mesophyll-cells are very short. 


\section{I40 Gibson.-Contributions towards a Knowledge of}

29. S. Lobbii, Moore.

Ventral leaf. The shape of the ventral, axillary, and dorsal leaves is that of the leaves of $S$. inaequalifolia. The margin of the ventral leaf is sclerotic but not spiny. Stomata occur on the aligular face only.

Dorsal leaf. Stomata distributed chiefly over the lamina on the aligular face-absent from the ligular epidermis.

Section. As in S. Wildenorviï.

30. S. gracilis, Moore.

Ventral leaf. Bluntly pointed, ovate or hastate with the bases produced, that on the side next the stem uncinate. A few stomata occur on the ligular face near the margins. The edges are smooth and sclerotic.

Dorsal leaf. Similar in shape, cuspidate. Stomata occur on the aligular surface only.

Section. As in S. Wildenorwii.

31. S. viridangula, Spr.

The leaves of this species are oblong oblique, the dorsal leaf cuspidate. The dorsal leaf has stomata on both ligular and aligular surfaces, but the ventral leaf has stomata on the aligular surface only.

Section. As in S. Wildenorvii.

32. S. chilensis, Spr.

Both ventral and dorsal leaves are lanceolate, almost equal-sided and with produced bases. Both have marginal sclerotic cells, but the margins are only very faintly spiny. A few stomata occur on the ligular face of the ventral leaf near the margin, but none occur on the same face of the dorsal leaf. In section both leaves conform to the type described for $S$. Wildenowii.

33. s. Victoriae, Moore.

Ventral and dorsal leaves are both oblique sickle-shaped, with blunt apices, sclerotic margins, and without marginal spines or hairs. The stomata, which occur only on the aligular face of the ventral leaf, are frequently clustered. Stomata occur on both sides of the dorsal leaf.

Section. The ligular epidermal cells are long, narrow, and closely packed, and merge into the reticulate mesophyll through an intermediate semi-palisade-layer. 
the Anatomy of the Gemus Selaginella, Spr. I4 I

The three following species have delicate leaves, and whilst retaining the characters of the species already described in so far as the epidermis is concerned, yet differ in having little or no mesophyll save in the immediate vicinity of the vascular bundle. Hence the ligular peg-like cells come to rest directly on the elongated epidermal cells of the aligular surface. In this respect a section of the leaf resembles that of S.canaliculata (Fig. 20), a species which might be considered as forming a transition to this section.

34. S. molliceps, Spr.

Ventral leaf. Ovoid but unequal-sided, delicate, with long warty sclerotic marginal cells, and spines which are especially long on the outer margin. Stomata occur over the midrib and along the margin, but are absent from the ligular face.

Dorsal leaf. Ovoid, but not so unequal-sided, and cuspidate, with spiny sclerotic margin. Stomata occur all round the margin and on the aligular face.

Section. The obconical ligular cells rest directly on the aligular epidermis.

35. S. apus, Spr.

Ventral leaf. Oblique, unequal-sided, acuminate, with a faintly spiny margin. Stomata occur on the aligular surface as well as near the margin.

Dorsal leaf. Oblique, tapering, slightly spiny. Stomata occur on the ligular surface near the margin, and occasionally actually on it. The aligular epidermal cells are warty, and stomata occur all over the surface.

Section. As in S. molliceps.

36. S. albonitens, Spr.

Ventral leaf. Lanceolate, acuminate, unequal-sided, faintly spiny along the margin. The polygonal cells of the ligular face have interspersed long sclerotic cells with stomata along the margin. Similar sclerotic cells occur among the elongated cells of the aligular face. Stomata are distributed over the entire surface, and a few occur on the margin itself.

Dorsal leaf. Ovate, with long pointed apex. The margin is spiny and warty. The ligular face is composed of elongated warty cells, 


\section{Gibson.-Contributions towards a Knowledge of}

some of them sclerotic, but bears no stomata. The aligular surface is composed of elongated wavy cells with interspersed sclerotic fibres and stomata over the entire surface, but not actually on the margins.

Section. As in S. molliceps.

I have already drawn attention to the variation in length and form of the epidermal cells in species with leaves of the Martensii-type, but one may say in general terms that the preceding thirty-five species have the ligular surface of the ventral leaf and the aligular of the dorsal leaf composed of polygonal cells, whilst the aligular surface of the ventral and ligular of the dorsal leaf are formed of cells obconic in section and with polygonal bases. In the succeeding species the epidermal layers on the ligular and aligular faces are approximately similar, and the cells are all elongated.

\section{B. Braunii-type.}

Three species come under this heading, viz. S. Braunii, S.concinna, and S. Bakeriana. All agree in that the epidermis of both the ligular and aligular surfaces consists of elongated sinuous cells, and in having a distinct palisade-layer as well as reticulate mesophyll. Indications of a palisade-layer in species of the Martensii-type have already been noted.

37. s. Braunii, Bak.

Ventral leaf. Ovoid with crenate or faintly spiny margins. The cells of the ligular face are elongated, verging to polygonal, whilst those of the aligular face are short with wavy margins. Numerous stomata occur on the aligular surface.

Dorsal leaf. Lancet-shaped, pointed, but without spines on the margin. The ligular epidermis, which bears stomata, is composed of short wavy margined cells, whilst the aligular surface is covered by polygonal or slightly elongated cells, with numerous stomata over the midrib.

Section. As in S. concinna.

38. S. concinna, Spr. (Figs. 7, 24, 25.)

The leaves are somewhat peculiar in shape. The ventral leaf is ovate but very unequal-sided, and has two long spiny backwardly 
the Anatomy of the Genus Selaginella, Spr. I43

directed lobes, one or both of which is frequently furcate. The ligular face consists of wavy bordered cells more elongated than in S. Braunii, without stomata, whilst the aligular face, composed of similar cells, bears stomata over the midrib, often sclerotic (Fig. 7). The dorsal leaf is ovate, and has a strongly sclerotic margin with elongated spiny apex. On the inner side there is a narrow basal lobe projecting backwards along the stem, on the outside the lobe is three or four times as broad. All the cells are warty (as are those of the ventral leaf also). Stomata occur on both faces.

Section. In section the ligular and aligular epidermal cells are seen to be strongly cuticularized and warty (Fig. 25). Beneath the ligular epidermis (of the ventral leaf) there occurs a well-marked palisadelayer of narrow deep cells, followed by a reticulate mesophyll resting on the aligular epidermis. At the margins the cells (Fig. 24) are seen to be entirely sclerotic, without intercellular spaces.

39. s. Bakeriana, Bail.

The ventral leaves are cordate, bluntly pointed and oblong. A few stomata occur on the margins, but none on the ligular face. Four to five rows of stomata occur on the aligular face. The margin is not sclerotic and very faintly spiny, or quite smooth.

Dorsal leaf. Ovate, pointed, with a faintly spiny margin. Stomata occur on the aligular face only.

Section. Like that of $S$. concinna, but the mesophyll is smaller in amount. A loose reticulum surrounds the bundle.

In the remaining species the epidermis of both the ligular and the aligular surfaces, composed of quite or nearly similar wavy-margined cells, is much elongated in the long axis of the leaf. In one only, S. Lyallii, there is a well-marked palisadelayer, usually double, as well as a reticulate mesophyll, which latter is alone, as a rule, present in the leaves of the remaining species. In a few, a pseudo-palisade-layer suggests a transition between the majority and the type just discussed.

\section{Galeottii-type.}

40. S. Galeottii, Spr. (Fig. 8.)

Ventral leaf. Broad, ovate, oblique, bluntly pointed, with a faintly spiny margin and a few long multicellular spines on the edge of the 


\section{I44 Gibson.-Contributions towards a Knowledge of}

basal lobes. Stomata occur on the aligular face only, the guard-cells of which are very frequently folded outwards into the adjacent epidermal cells (Fig. 8).

Dorsal leaf. Oblique hastate, with backwardly directed basal lobes and numerous multicellular hairs. Stomata occur on the aligular face only.

Section. As in S. delicatissima.

41. S. delicatissima, A. Br. (Fig. I 8.)

Ventral leaf. Ovate oblique, with warty and spiny marginal cells not sclerotic. Stomata occur between the spines along the margin and on the aligular face, but not on the ligular side.

The dorsal leaf is similar in shape, and stomata occur over the midrib and outside edge.

Section. The ligular surface (of the ventral leaf) consists of large cells, tabular in section, followed by an ill-defined layer of peg-shaped cells with one to three chloroplastids in each, with their truncated ends continuous with long branched and reticulate mesophyll-cells, each with many small chloroplastids. The cuticle on both surfaces is very delicate (Fig. 18).

42. S. sulcata, Spr.

Ventral and dorsal leaves of this species are hastate, and bear wellmarked basal lobes with a fringe of multicellular hairs. The margins of both leaves are smooth, or only faintly spiny. Stomata occur only on the aligular faces of the dorsal and ventral leaf.

In section the pseudo-palisade-layer is absent, but the ligular epidermis is composed of cells resembling in section the peg-shaped polygonal based cells of the ligular epidermis in the leaves of the Martensiz-type.

43. S. Kraussiana, A. Br.

Ventral leaf. Oblique, pointed, unequal-sided, with spiny margins and warty marginal cells. Numerous stomata occur on the margin and on the ligular surface near it, as well as over the midrib on the aligular face.

Dorsal leaf. Oblique, pointed, and unequal sided, in outline like that of a Begonia leaf. The margin has short spines. Marginal stomata occur on the ligular face, and also over the midrib on the aligular face.

Section. As in $S$. delicatissima. 


\section{S. Poulteri, Hort.}

Ventral leaf. Nearly circular or slightly oblique, slightly pointed, with a faintly spiny margin. Stomata occur along the margin and near it; also on the ligular surface. The aligular epidermis consists of elongated cells with exceedingly wavy margins and with a few sclerotic fibres interspersed.

Dorsal leaf. Oblong oblique with backwardly directed basal lobe and spiny margins. Stomata occur here also on the ligular face near the margin.

Section. As in S. delicatissima.

\section{S. rubella, Moore.}

The ventral and dorsal leaves are somewhat like those of S. Poulteri in form. The margins are faintly spiny. Stomata occur on the margin, and along the edge of the ligular face. Warty sclerotic cells and stomata are frequent on the aligular surface.

The dorsal leaf is peltate, the basal lobes joining behind the point of insertion of the leaf. There are no stomata on the ligular face, but they occur plentifully on the aligular surface. All the cells of the latter face are warty.

Section. As in S. delicatissima.

46. S. lepidophylla, Spr.

The ventral and dorsal leaves are both elongated ovate with delicate tapering apices and of nearly the same size. The cordate bases are fringed with hairs, and the margins are warty and spiny. The cells of both ligular and aligular faces of both leaves are strongly sclerotic. Stomata occur on both ligular and aligular faces of both ventral and dorsal leaves. As already stated (p. I 27), Wojinowić and Erikson state that although stomata occur on both sides of the ventral leaf, they are absent from the aligular face of the dorsal leaf. I have examined a large number of dorsal leaves from several plants, and never failed to find stomata both on the ligular and aligular epidermis.

Section. The mesophyll consists of reticulate parenchyma only.

47. S. involvens, Spr.

The leaves are rhomboid and fringed with spiny processes. The apices are long and tapering, like those of $S$. lepidophylla. The epidermis of both sides is like that of the preceding species, and 


\section{I46 Gibson.-Contributions towards a Knowledge of}

stomata occur on both ligular and aligular faces of both dorsal and ventral leaves.

In section the leaf resembles $S$. helvetica (Fig. 23), but the cells of the reticulate mesophyll next the ligular face are more closely packed, forming a pseudo-palisade-layer. Distinct emergences occur on the basal lobes, consisting of three, four, or more thick-walled spines, fused together.

48. s. pilifera, A. Br.

The leaves of this species are very similar to those of $S$. involvens. The apices are long, and the margins are sclerotic and very spiny. Stomata occur on both ligular and aligular faces of both ventral and dorsal leaves.

The leaf in section shows the same characters as that of the preceding species.

The remaining three species belonging to this series differ from those already described in having spirally arranged similar leaves. In structure, however, they closely resemble those of the Galeottii-type. All three have strongly sclerotic leaf-cells of dense and firm texture. The leaves are further equal-sided and fringed with well-marked spines or emergences. The reticulate mesophyll is large in amount, and there is no palisade-layer.

\section{Spinosa-type.}

49. S. spinosa, A. B. (Fig. 26.)

The leaves of the erect vegetative axis are approximately similar. The first leaves on the creeping portion of the stem, which are often opposite or nearly so, are ovate acuminate and placed far apart. Their margins are entire, or have one or two multicellular spines. On the erect axis the leaves become more lanceolate and pointed, and have two to four prominent recurved spines on either side. The margins of all the leaves are strongly cuticularized.

The ligular epidermis of the leaf of the prostrate axis is composed of oblong cells with wavy margins. The aligular epidermis is similar in character. Siomata occur on the aligular face only. A few stomata occur along the margin where the cuticularized thick-walled cells are absent. 


\section{the Anatomy of the Genus Selaginella, Spr. I47}

The epidermal characters of the leaves of the erect stem are similar to those of the leaves of the creeping axis. Stomata occur on the aligular face, rarely along the margins.

In section the mesophyll-cells are found to be homogeneous in character, and all are more or less elongated in the long axis of the leaf, forming a loose reticulum. In older leaves the aligular epidermis shows a tendency to separate from the mesophyll (Fig. 26).

50. S. rupestris, Spr. (Figs. 27, 28.) .

As in the preceding species, the leaves are homophyllous, elongate lanceolate, with long spiny cusps, and margins fringed with unicellular spines. The ligular epidermis consists of elongated wavy cells with warty cuticle. No stomata occur on this face. The stomata on the aligular surface are confined to a groove situated above the midrib.

In section the leaf is boat-shaped. A sclerotic hypoderma, one or two cells deep, occurs on the lateral wings beneath the epidermis. The mesophyll towards the aligular surface consists of much elongated branched and anastomosing cells; towards the aligular face the cells are much shorter (Figs. 27, 28).

51. S. oregana, Eat.

The leaves in form and histological structure are almost precisely similar to those of S. rupestris.

\section{E. Lyallii-type.}

\section{S. laevigata, Bak., var. Lyallii, Spr. (Fig. I 7.)}

As in the case of the stem, this species differs somewhat in its leafstructure from those already described.

The ventral leaf is ovoid, equal-sided, and bluntly pointed with a smooth margin. The dorsal leaf is more elongated and lanceolate, without marginal spines. Both have descending wings adnate to the stem.

The ventral leaf. The edge is composed of elongated thick-walled cells with little chlorophyll. The epidermis of both surfaces consists of elongated rhombic plates with wavy outlines. Several rows of stomata occur on the aligular face, close to and over the midrib, where the epidermal cells are much shorter. There are no stomata on the ligular face. The dorsal leaf has quite similar characters.

L 2 


\section{I48 Gibson.-Contributions towards a Knowledge of}

In section (Fig. I 7 ) the ligular epidermis is followed by a very distinct palisade-layer, one or, in many places, two cells deep. The main mass of the leaf is occupied by reticulate mesophyll, absent however at the margins and apex. The vascular bundle consists, in section, of three strands of spiral tracheides, the central strand being surrounded by phloem, and all three imbedded in small-celled parenchyma without intercellular spaces.

\section{Section II. Comparative Anatomy.}

\section{The distribution of the Stomata.}

In comparing the different species, one is struck by the great variation in the distribution of the stomata on the leaf. As has been pointed out in the discussion of the individual species, stomata may occur on the ligular or aligular surfaces, or on both; generally over the midrib, but frequently on the marginal lamellae or even on the margin itself. A glance at the following tabular statement shows that out of fifty-two species examined, fourteen species and one variety have stomata on the aligular face only of both dorsal and ventral leaves; ten species and two varieties have stomata also on the ligular face of the ventral leaves; eight have stomata on the ligular face of the dorsal but not on the corresponding face of the ventral leaf; ten species have stomata on both ligular and aligular faces of both types of leaf; whilst twelve species have stomata actually on the margin either of the dorsal or ventral leaf, or not removed more than one cell from it. One can say therefore, though only in very general terms, that the stomata in the genus are distributed as a rule on the aligular epidermis.

2. Structure and development of the Stomata (Figs. I2, 13).

I have followed out the stages in the development of the stomata in several species-e.g. S. uncinata (Figs. I2, I3), S. Kraussiana, \&c. - and find no essential differences between them. The stomata appear to be quite of the normal phanerogamic type, with two guard-cells, each provided with a nucleus and a variable number of chloroplastids, not infre- 
STOMATA OCCUR ON THE

\begin{tabular}{|c|c|c|c|c|c|}
\hline \multicolumn{3}{|c|}{ VENTRAL LEAF. } & \multicolumn{3}{|c|}{ DORSAL LEAF. } \\
\hline Ligular face. & Aligular face. & Margin. & Ligular face. & Aligular face. & Margin. \\
\hline $\begin{array}{l}\text { S. inaequalifolia } \\
\text { S. Wallichii } \\
\text { S. canaliculata } \\
\text { S. Mettenii } \\
\text { S. gracilis } \\
\text { S. chilensis } \\
\text { S. plumosa } \\
\text { S. Douglasii } \\
\text { S. albonitens }\end{array}$ & $\begin{array}{l}\text { S. Martensii } \\
\text { S. grandis } \\
\text { S. Vogelii } \\
\text { S. haematodes } \\
\text { S. erythropus } \\
\text { S. caulescens } \\
\text { "y var. japonica } \\
\text { "y var. minor } \\
\text { ', var. argentea } \\
\text { S. Griffithii } \\
\text { S. Karsteniana } \\
\text { S. suberosa } \\
\text { S. stenophylla } \\
\text { S. viticulosa } \\
\text { S. serpens } \\
\text { S. cuspidata } \\
\text { S. helvetica } \\
\text { S. denticulata } \\
\text { S. patula } \\
\text { S. convoluta } \\
\text { S. flabellata } \\
\text { S. producta } \\
\text { S. bisulcata } \\
\text { S. uncinata } \\
\text { S. inaequalifolia } \\
\text { S. Wallichii } \\
\text { S. Wildenowii } \\
\text { S. canaliculata } \\
\text { S. Mettenii } \\
\text { S. Lobbii } \\
\text { S. gracilis } \\
\text { S. viridangula } \\
\text { S. chilensis } \\
\text { S. Victoriae } \\
\text { S. plumosa } \\
\text { S. Douglasii } \\
\text { S. molliceps } \\
\text { S. apus } \\
\text { S. albonitens } \\
\text { S. Bakeriana } \\
\text { S. Braunii } \\
\text { S. concinna } \\
\text { S. Galeottii } \\
\text { S. delicatissima } \\
\text { S. sulcata } \\
\text { S. Kraussiana } \\
\text { S. Poulteri } \\
\text { S. rubella } \\
\text { S. lepidophylla } \\
\text { S. involvens } \\
\text { S. pilifera } \\
\text { S. spinosa } \\
\text { S. rupestris } \\
\text { S. oregana } \\
\text { S. Lyallii } \\
\text { Slata }\end{array}$ & $\begin{array}{l}\text { S. molliceps } \\
\text { S. apus } \\
\text { S. albonitens } \\
\text { S. Bakeriana } \\
\\
\text { S. delicatissima } \\
\text { S. Kraussiana } \\
\text { S. Poulteri } \\
\text { S. rubella }\end{array}$ & $\begin{array}{l}\text { S. Wallichii } \\
\text { S. viridangula } \\
\text { S. Victoriae } \\
\text { S. Douglasii } \\
\text { S. apus } \\
\text { S. Braunii } \\
\text { S. concinna } \\
\\
\text { S. Kraussiana } \\
\text { S. Poulteri } \\
\text { S. lepidophylla } \\
\text { S. involvens } \\
\text { S. pilifera }\end{array}$ & $\begin{array}{l}\text { S. Martensii } \\
\text { S. grandis } \\
\text { S. Vogelii } \\
\text { S. haematodes } \\
\text { S. erythropus } \\
\text { S. caulescens } \\
\text { "y var. japonica } \\
\text {," var. minor } \\
\text { S. var. argentea } \\
\text { S. Griffithii } \\
\text { S. Karsteniana } \\
\text { S. suberosa } \\
\text { S. stenophylla } \\
\text { S. viticulosa } \\
\text { S. serpens } \\
\text { S. cuspidata } \\
\text { S. helvetica } \\
\text { S. denticulata } \\
\text { S. patula } \\
\text { S. convoluta } \\
\text { S. flabellata } \\
\text { S. producta } \\
\text { S. bisulcata } \\
\text { S. uncinata } \\
\text { S. inaequalifolia } \\
\text { S. Wallichii } \\
\text { S. Wildenowii } \\
\text { S. canaliculata } \\
\text { S. Mettenii } \\
\text { S. Lobbii } \\
\text { S. gracilis } \\
\text { S. viridangula } \\
\text { S. chilensis } \\
\text { S. Victoriae } \\
\text { S. plumosa } \\
\text { S. Douglasii } \\
\text { S. molliceps } \\
\text { S. apus } \\
\text { S. albonitens } \\
\text { S. Bakeriana } \\
\text { S. Braunii } \\
\text { S. concinna } \\
\text { S. Galeottii } \\
\text { S. delicatissima } \\
\text { S. sulcata } \\
\text { S. Kraussiana } \\
\text { S. Poulteri } \\
\text { S. rubella } \\
\text { S. lepidophylla } \\
\text { S. involvens } \\
\text { S. pilifera } \\
\text { S. spinosa } \\
\text { S. rupestris } \\
\text { S. oregana } \\
\text { S. Lyallii } \\
\text { S. }\end{array}$ & $\begin{array}{l}\text { S. Karsteniana } \\
\text { S. suberosa } \\
\text { S. stenophylla }\end{array}$ \\
\hline
\end{tabular}




\section{I50 Gibson.-Contributions towards a Knowledge of}

quently two only. In some species, e.g. S. viticulosa, stomata with three or even four guard-cells may be found, similar to those described and figured by Haberlandt ${ }^{1}$ as occurring in the sporogonium of Mosses, and by Farmer $^{2}$ in Iris. The dermatogenic layer immediately over the midrib undergoes division so as to form a band of variable breadth of almost square cells, at first (i.e. near the base of the young leaf) quite indistinguishable from each other. Presently some of these cells, after division has ceased, become rounded and contain denser protoplasm; these are the mother-cells of the stomata. The dermatogenic cell therefore becomes the mother-cell of the stoma directly, and undergoes division by formation of a vertical wall in the long axis of the leaf. In some cases this wall is oblique. The median wall splits, and a central elliptical pore is formed, as in the normal mode of formation of stomata. In the older leaves of many species the walls both of the guard-cells and of the surrounding epidermal cells become greatly thickened, as, for example, in S. Martensii, S.producta, S.concinna, S. viticulosa, \&c. The stomata, which are in some species formed directly on the margin, do not appear to differ in any respect from those of other parts of the leaf.

\section{The Epidermal Cells (Figs. 6, I I, I2, I3, I6, \&c.).}

Reference has already been made under the individual species to the great variety in length and general form of the epidermal cells. Generally speaking, one may distinguish three types of cell in the superficial layer of the leaf: (I) conical cells, having their somewhat square or more commonly polygonal bases turned outwards, and their truncated ends in continuity with the mesophyll (Fig. 22); (2) elongated, squareended, or tapering plates, with more or less sinuous lateral walls (Figs. 6, 1I) ; (3) sclerotic, warty, and elongated fibres, which occur along the margin in many species (Fig. 4), or scattered irregularly amongst the epidermal cells of either of the two preceding types (Figs. I1, 16, 19). Even on the

${ }^{1}$ Beiträge zur Anatomie und Physiologie der Laubmoose. Pringsh. Jahrb. XVII. 3. 1886.

${ }^{2}$ Ann. Bot., No. xiii, p. I 74 . 
same leaf-surface one finds polygonal cells near the stomata over the midrib, whilst on the margins and base the cells are of the elongated type.

\section{The Mesophyll.}

The mesophyll varies also very greatly in amount, and also in the form of its component elements. In general the main mass of the leaf consists of a reticulum of longer or shorter cells (compare Figs. I 8 and 29) with comparatively large intercellular spaces. In certain species a pseudo-palisade-layer is formed, either of the terminal superficial cells of the reticulum (Fig. 23), or of special smaller cells connected with the reticulum (Fig. 2I). In other cases, again, a quite definite palisade-layer is formed, as in S. concinna (Fig. 25) and S. Lyallii (Fig. 17). Towards the edges of most leaves, and in some cases (e.g. S. molliceps, \&c.) throughout the entire leaf (save immediately round the vascular bundle), the mesophyll is entirely wanting, and the two epidermal layers are in contact. In such cases the guard-cells of the stomata are very shallow, and since the aligular epidermal cells are deep, a well-marked respiratory and transpiratory cavity is left, even in a leaf only two cells thick.

\section{The Vascular Bundle.}

The vascular bundle is almost invariably simple, and extends on an average through five-sixths of the length of the leaf. In some cases it reaches to the base of the cusp, but never (so far as I have seen) enters it. In one or two cases, e.g. S. molliceps, I have found a bifurcate midrib, but this so rarely that I am forced to believe that the bifurcate condition is to be explained as a mere sport.

In structure the bundle is very simple. In S. Kranssiana, for instance, the xylem of the midrib near the base and as far as the middle of the leaf consists of four to five delicate tracheides, of which as a rule one is annular, the rest spiral, the spiral being the first to appear. In the upper third of the leaf the protoxylem-elements become accompanied by several short reticulate tracheides which flank the 


\section{I52 Gibson-Contributions towards a Knowledge of}

spiral tracheides, and in section (e.g. of S. Braunii) may enclose the spiral elements completely. In all cases which I have examined the vein is much more delicate nearer the base of the leaf, and expands at its apex. In the very young leaf of $S$. Kraussiana the reticulate elements at the apex may be fully developed before the differentiation of the characteristic markings on the spiral and annular tracheides. The xylem is partly surrounded by a few long and narrow parenchyma-cells, and one or two sieve-tubes with characteristic plates are present if the bundle be at all massive. In many cases I was quite unable to convince myself that genuine sieve-tubes were present. All the tubes investing the xylem are elongated, thin-walled, and contain nuclei and protoplasm. These again are surrounded by a layer of larger cells without intercellular spaces, usually containing a small amount of chlorophyll, which may be considered as a peridesm. I find no evidence of the existence of a genuine endodermis, save just at the base of the leaf, where cells comparable to and in direct continuity with the endodermal cells of the stele occur. The midrib of $S$. Lyallii is somewhat irregular in character. The xylem-elements are arranged in three patches; the central strand alone has genuine sieve-tubes on its aligular face, but each of the three strands is surrounded by parenchyma, and all three are enclosed in a definite layer (probably peridesm), abutting on reticulate mesophyll below and palisade-cells above (Fig. 17 ).

In a previous paper ${ }^{1} \mathrm{I}$ called attention to certain types of stem-structure in the genus Selaginella, and made a comparison between the grouping of species based on such anatomical characters and that usually accepted by systematists. Considering the anatomy of the stem only, the majority of species examined may be grouped round S. Martensii, all characterized by the presence of a single stele and by dorsiventrality both of external morphological features and internal anatomy. $S$. uncinata formed a transition-type to that of $S$. inaequali-

1 On the diagnostic characters of the subgenera and species of Selaginella: Trans. Biol. Soc. Liverponl, I 895 . 
folia; the former shows a distinct tendency to that splitting of the single stele into dorsal, median, and ventral steles, which is carried to its extreme in the latter type. All the species which have the Martensii-type of leaf belong to the monostelic and tristelic series as defined in that paper. A few species, also monostelic so far as their stem-structure is concerned, vary somewhat from the normal type of leafstructure. S. molliceps, S. apus, and S. albonitens present no difficulty, seeing that their leaves differ from the Martensiitype only in having the reticulate mesophyll reduced to a minimum. S. Bakeriana, S. Bramiii, and S. concinna, on the other hand, differ from the Martensii-type in two respects; viz. in having a more or less distinct palisade-layer, and in that the epidermis of the ligular and aligular surfaces is more or less similar. As I have, however, tried to point out above, the length of the epidermal cells is by no means constant even in the same species; and several species belonging to the Martensii-type, e.g. S. helvetica and S. plumosa, form pseudo-palisade-layers, so that these three species are perhaps not so aberrant as they at first sight appear. In the series with quite equivalent epidermis on the ligular and aligular faces, we find all the species with two laterally placed steles, e.g. S. Kraussiana, as well as a few monostelic species. Of these latter, three (S. pilifera, S.lepidophylla, and S. involvens) have a peculiar in-rolling habit, which may have something to do with the equivalence of the epidermis on both leafsurfaces, whilst the remaining three (S. mpestris, S. spinosa, and $S$. oregana) are homophyllous. S. Lyallii is peculiar not only in regard to the anatomy of its stem, but also in its leaf-structure. Looking at the genus as a whole (at all events the fifty-two species here discussed), one may say that there are three chief types of stem-structure: the dorsiventral monostelic, leading to the tristelic, and the lateral bistelic. The leaf, of course, is much more likely to be liable to the influence of the environment than the internal anatomy of the stem, and therefore it is less to be depended upon for classificatory purposes. Still, it is interesting to note that, with the 


\title{
I54 Gibson.-Contributions towards a Knowledge of
}

few not extremely important exceptions noted, all the species with heterogeneous leaf-epidermis belong to the dorsiventral monostelic or allied tristelic types; whilst those with two laterally-placed steles have homologous leaf-epidermis. Without pressing the point too much, one may, I think, say that, on the whole, a classification of these fifty-two species based on the anatomy of the stem is supported by the structure of the leaf.

\section{EXPLANATION OF FIGURES IN PLATE IX.}

\author{
Illustrating Professor Harvey Gibson's paper on the leaf of Selaginella.
}

Fig. I. A trichome from the margin of the ventral leaf of $S$. Douglasii, with basal investment of marginal cells. $\times 35^{\circ}$.

Fig. 2. Adjacent stomata of S. viticulosa. $\times 35^{\circ}$.

Fig. 3. Thick-walled stomata of S. Martensii. $\times 35^{\circ}$.

Fig. 4. Margin of the ventral leaf of $S$. serpens, showing semi-occluded unicellular spines. $\times 350$.

Fig. 5. Stoma of $S$. producta, showing great thickening in surrounding epidermal cells. $\times 35^{\circ}$.

Fig. 6. Aligular epidermis of the ventral leaf of S.producta. The cells have localized thickenings. $\times 35^{\circ}$.

Fig. 7. Stoma of S. concinna, with almost occluded guard-cells. $\times 35^{\circ}$.

Fig. 8. Stoma of S. Galeottii. $\times 450$.

Figs. 9, 10. Stomata of $S$. viticulosa. One is figured with three guard-cells. $\times 35$.

Fig. II. Aligular epidermis of ventral leaf of $S$. patula. One of the warty sclerotic fibres is shown. $\times 35^{\circ}$.

Figs. I2, I3. Development of stomata from a young dorsal leaf of S. uncinata. $\times 55^{\circ}$.

Fig. I4. Marginal spine of S. serpens. $\quad \times 35^{\circ}$.

Fig. I5. Multicellular trichome from the basal lobe of the ventral leaf of S. sulcata. $\times 450$.

Fig. I6. Sclerotic fibre with two rows of warts from the aligular face of the ventral leaf of $S$. viticulosa. $\quad \times 35^{\circ}$.

Fig. I7. Transverse section of the ventral leaf of S. Lyallii. $\times 35^{\circ}$. (For description see text.)

Fig. 18. Transverse section of the ventral leaf of S. delicatissima. $\quad \times 35^{\circ}$. 


\section{the Anatomy of the Gemus Selaginella, Spr. I55}

Fig. 19. Transverse section of the ventral leaf of $S$. suberosa. Three of the sclerotic fibres are shown. $\times 35^{\circ}$.

Fig. 20. Transverse section of the ventral leaf of $S$. canaliculata near the margin. $\times 350$.

Fig. 2I. Transverse section, ventral leaf of $S$. plumosa. $\quad \times 35^{\circ}$.

Fig. 22. Transverse section, ventral leaf of S. viticulosa. $\quad \times 35^{\circ}$.

Fig. 23. Longitudinal section of the ventral leaf of S. helvetica. $\times 350$.

Figs. 24, 25. S. concinna: Fig. 24 from the margin of the leaf, Fig. 25 from near the midrib. $\times 35^{\circ}$.

Fig. 26. Transverse section, leaf of S. spinosa. $\quad \times 350$.

Figs. 27,28 . S. rupestris: Fig. 27 , a longitudinal section, $\times 35^{\circ}$; Fig. 28 , transverse section, $\times 75$.

Fig. 29. Transverse section of the ventral leaf of $S$. serpens.

Figs. 30, 31. S. Wildenowii, Fig. 30 from near the margin; Fig. $3 \mathrm{I}$ through the midrib. $\times 35^{\circ}$. The latter section is taken across the upper half of the leaf, where the xylem of the vascular bundle consists chiefly of reticulate elements. 


\section{Annats of Botany}

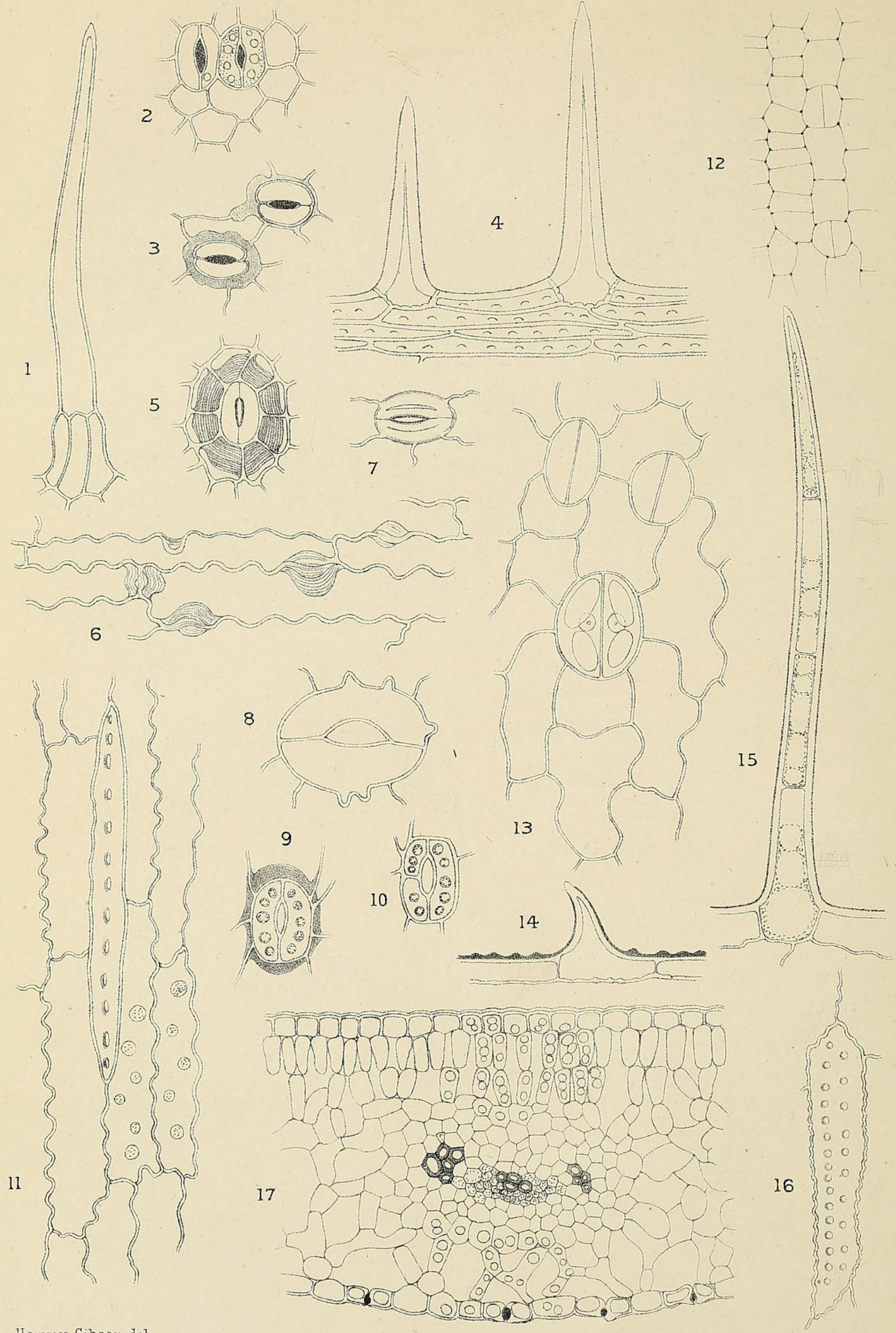

Harvey Gibson del

HARVEY GIBSON. - SELAGINELLA. 
Vol.XI, PLIX.

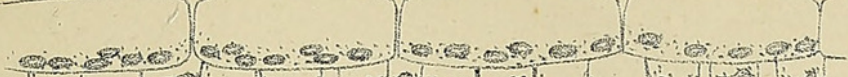

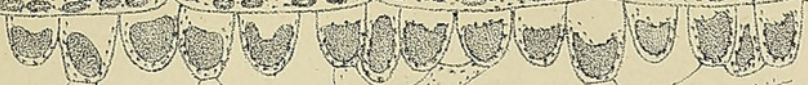

18

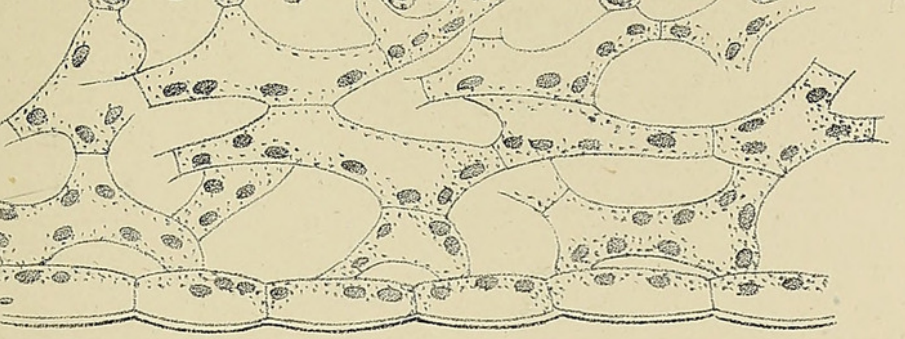

20

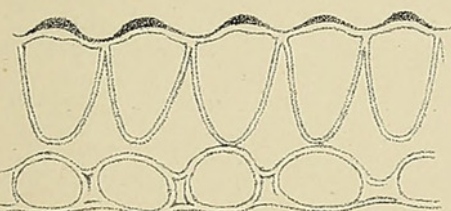

21 (3) 0 ol 0

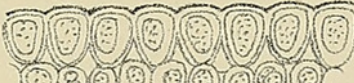

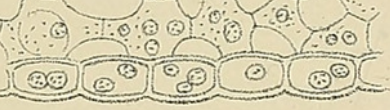

23
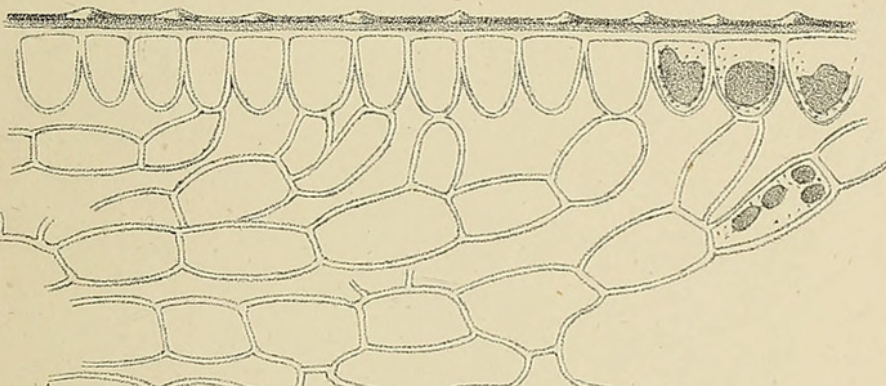

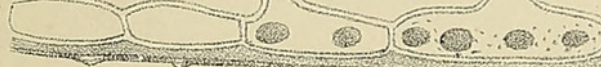

22

19

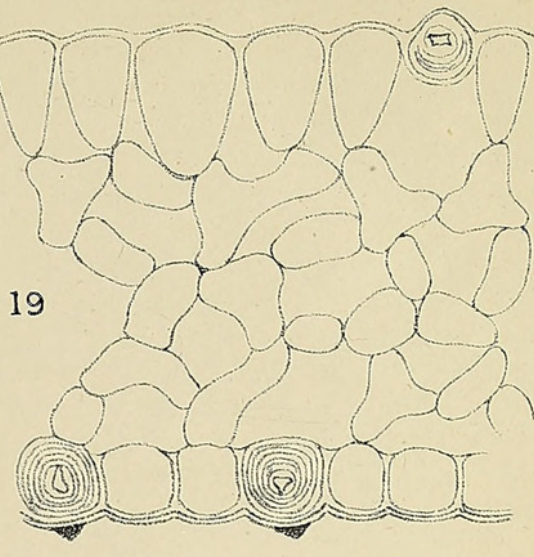

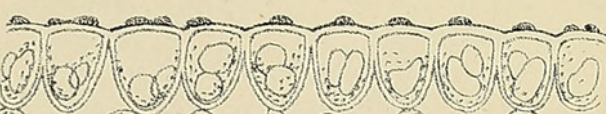
(8) (3) (3) (3) $00 \%$ o 80

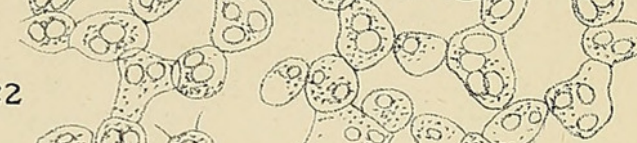
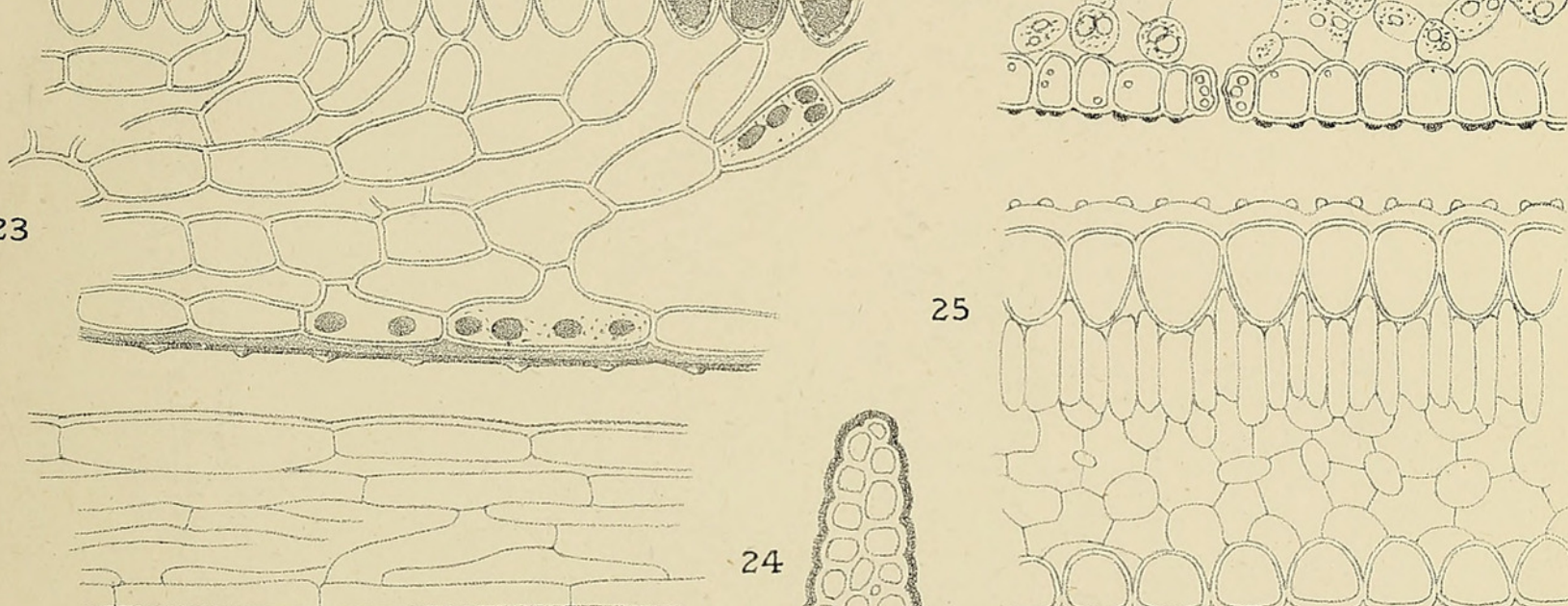

27
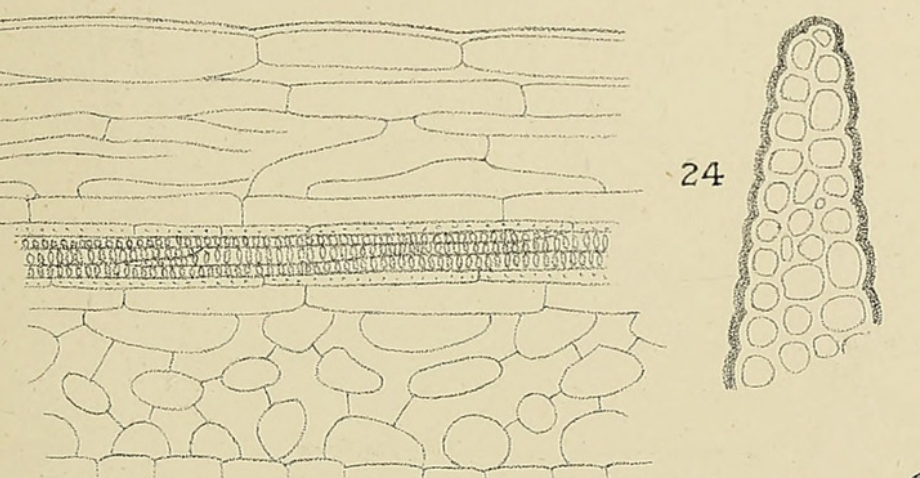

3808,58000005

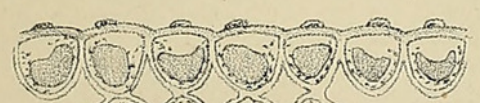
3. 50.000

29

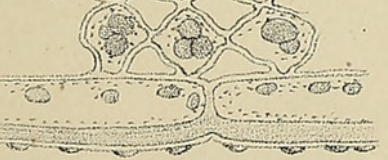

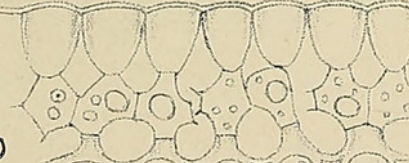

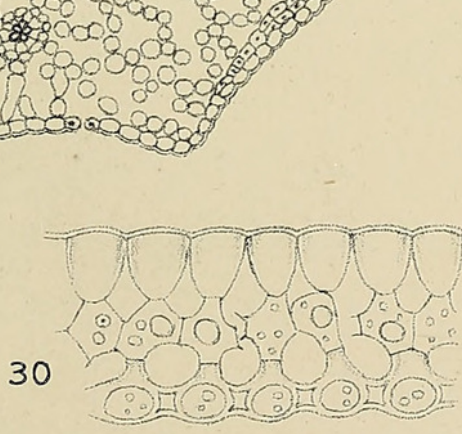

26

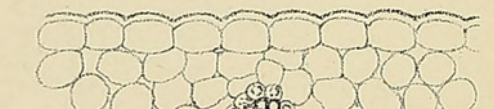

31

(1)

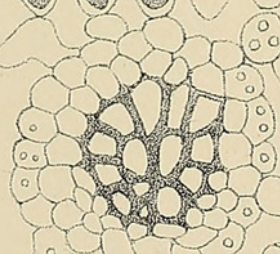




\section{$2 \mathrm{BHL}$ Biodiversity Heritage Library}

Harvey-Gibson, R. J. 1897. "Contributions towards a knowledge of the anatomy of the genus Selaginella, Spr." Annals of botany 11, 123-155. https://doi.org/10.1093/oxfordjournals.aob.a088639.

View This Item Online: https://www.biodiversitylibrary.org/item/233542

DOI: https://doi.org/10.1093/oxfordjournals.aob.a088639

Permalink: https://www.biodiversitylibrary.org/partpdf/318456

\section{Holding Institution}

Smithsonian Libraries

\section{Sponsored by}

Biodiversity Heritage Library

\section{Copyright \& Reuse}

Copyright Status: Not in copyright. The BHL knows of no copyright restrictions on this item.

This document was created from content at the Biodiversity Heritage Library, the world's largest open access digital library for biodiversity literature and archives. Visit BHL at https://www.biodiversitylibrary.org. 